\title{
CHANGES IN CHEMICAL PROPERTIES BY USE AND MANAGEMENT OF AN OXISOL IN THE AMAZON BIOME ${ }^{1}$
}

\author{
MARCOS RODRIGUES ${ }^{2 *}$, FLÁVIO HENRIQUE SILVEIRA RABÊLO ${ }^{3}$, HEBER AUGUSTO DE CASTRO ${ }^{4}$, \\ DELMONTE ROBOREDO ${ }^{4}$, MARCO ANTONIO CAMILLO DE CARVALHO ${ }^{4}$, CASSIANO GARCIA ROQUE ${ }^{5}$
}

\begin{abstract}
The proper soil use and management are essential for a sustainable production, thus the pursuit for systems that minimize damages to the environment and improve soil fertility is continuous. The objective of this study was to evaluate changes in soil fertility by the use and management of an Oxisol (Latossolo Vermelho-amarelo, SiBCS) in the Amazon biome. The soil uses and management systems evaluated were native forest, native pasture, minimum tillage system and conventional tillage system. The chemical atributes of the soil layers $0.00-0.10,0.10-0.20,0.20-0.30$ and $0.30-0.40 \mathrm{~m}$ were evaluated. The soil $\mathrm{pH}\left(\mathrm{CaCl}_{2}\right)$ and the contents of organic matter, available phosphorus and exchangeable potassium, calcium, magnesium and aluminum were evaluated and the saturation by $\mathrm{Al}$, effective cation exchange capacity and soil potential were determined. The highest $\mathrm{pH}$ values were found in the native pasture area, and the highest exchangeable aluminum contents were found in the layers $0.00-0.10$ and $0.10-0.20 \mathrm{~m}$ of the conventional tillage system. The highest phosphorus availability was found in the layer $0.00-0.10 \mathrm{~m}$ of the native forest area. The highest potassium availability was found in the minimum tillage system. The lowest calcium and magnesium values were found in the layers $0.00-0.10$ and $0.10-0.20 \mathrm{~m}$ of the conventional tillage system. The highest soil organic matter content was found in the layer $0.00-0.10 \mathrm{~m}$ of the native forest area. The nutrient availability for plants decreases in soils managed using the conventional tillage system. Soil uses and management systems of little soil disturbance are recommended to minimize environmental degradation in the Amazon biome.
\end{abstract}

Keywords: Brachiaria brizantha. Minimum tillage. Conventional tillage. Environmental degradation. Sustainable management.

\section{ALTERAÇÕES NOS ATRIBUTOS QUÍMICOS DO SOLO PELO USO E MANEJO EM LATOSSOLO NA AMAZÔNIA}

RESUMO - O uso e manejo do solo adequados são fundamentais para a produção sustentável, sendo constante a busca por sistemas que minimizem os danos causados ao ambiente e que melhorem a fertilidade do solo. Objetivou-se avaliar as alterações nos atributos de fertilidade em decorrência do uso e manejo em Latossolo Vermelho-Amarelo (LVA) na Amazônia. Os seguintes sistemas de uso e manejo do solo num LVA foram avaliados: floresta nativa, pastagem nativa e áreas preparadas por sistema de cultivo mínimo e cultivo convencional. As avaliações dos atributos químicos do solo foram realizadas nas profundidades de 0-0,10, 0,10-0,20, 0,20-0,30 e 0,30-0,40 m. Foram avaliados o $\mathrm{pH}$ do solo $\left(\mathrm{CaCl}_{2}\right)$, o teor de matéria orgânica do solo, os teores de fósforo disponível e potássio trocável, cálcio, magnésio e alumino trocáveis, sendo ainda determinados a saturação por Al, a capacidade de troca catiônica efetiva e potencial do solo. Os valores de $\mathrm{pH}$ mais elevados foram verificados no sistema de pastagem nativa e os maiores teores de alumínio trocável nas profundidades de 0-0,10 e 0,10-0,20 m foram verificadas no sistema de cultivo convencional. O sistema de floresta nativa apresentou a maior disponibilidade de fósforo na profundidade de 0-0,10 $\mathrm{m}$. As maiores disponibilidades de potássio foram verificadas no sistema de cultivo mínimo. Os menores valores de cálcio e magnésio nas profundidades de 0-0,10 e 0,10-0,20 m ocorreram no sistema de cultivo convencional. O sistema de floresta nativa apresentou o maior teor de matéria orgânica do solo na profundidade de $0-0,10 \mathrm{~m}$. A disponibilidade de nutrientes para as plantas é reduzida em solos manejados em sistema de plantio convencional. Os sistemas de uso e manejo de menor revolvimento do solo são indicados para minimizar a degradação ambiental na Amazônia.

Palavras-chave: Brachiaria brizantha. Cultivo mínimo. Cultivo convencional. Degradação ambiental. Manejo sustentável.

\footnotetext{
*Corresponding author

${ }^{1}$ Received for publication in $08 / 18 / 2014$; accepted in 07/29/2016.

Paper accepted from the third author's undergraduate thesis.

${ }^{2}$ Department of Soil Science, Escola Superior de Agricultura “Luiz de Queiroz”, Piracicaba, SP, Brazil; rodrigues.m@usp.br.

${ }^{3}$ Laboratory of Mineral Nutrition of Plants, Centro de Energia Nuclear na Agricultura, Piracicaba, SP, Brazil; flaviohsr.agro@yahoo.com.br.

${ }^{4}$ Department of Agronomy, Universidade do Estado de Mato Grosso, Alta Floresta, MT, Brazil; heber.augusto.c@hotmail.com, roboredo@gmail.com, marcocarvalho@unemat.br.

${ }^{5}$ Department of Agronomy, Universidade Federal do Mato Grosso do Sul, Chapadão do Sul, MS, Brazil; cassiano.roque@ufms.br.
} 


\section{INTRODUCTION}

Seventy-two million hectares of the Brazilian Amazon biome was deforested in recent decades, of which fifty-six millions are converted into pastures and more than half are in advanced degradation state (DE SOUZA BRAZ; FERNANDEZ; ALLEONI, 2013; SILVA NETO et al., 2012), due mainly to inadequate soil and crop managements. Inadequate soil managements potentially contribute to environmental degradation, since it negatively changes the soil physical, chemical and biological characteristics (SILVA NETO et al., 2011). This processes are even more serious in the Amazon region, in which the conversion into pastures occurs often after the use of burning practices (TOWNSEND; COSTA; PEREIRA, 2010) and soil tilling by plowing and harrowing, causing destruction of aggregates, decrease of organic matter content in the soil surface layers and increase of water erosion (BAYER; BERTOL, 1999; MOREIRA; MALAVOLTA, 2004; SATO et al., 2012). Thus, the soil uses in this region must be carefully planned, implementing soil conservation practices from the beginning, in order to preserve the soil productive potential (MULLER et al., 2001).

The minimum tillage system is an alternative to minimize the impacts to the environment, whose adoption aims to disrupt compacted layers, increase water infiltration and reduce soil disturbances (SASAKI; GONÇALVES; BENTIVENHA, 2005). The intensity of soil tilling and incorporation of crop residues carried out for soil management, promote changes in $\mathrm{pH}$, ion dynamics, organic matter content and cation exchange capacity (CEC) of the soil, which are intensified with the time of use of the area (MARCOLAN et al., 2007). Falleiro et al. (2003) assessed the effect of tillage systems (no-tillage, minimum tillage and conventional tillage) on soil chemical properties and found that the values of $\mathrm{pH}$, calcium, magnesium, phosphorus, organic matter and effective CEC of the soil, under conventional tillage system, decreased compared with the other management systems, decreasing soil fertility and causing early soil degradation process. Santos et al. (2008) also reported the use of conservationist systems (no-tillage and minimum tillage) resulting in better soil fertility than the conventional system after 20 years of use.

Soil management is essential for agricultural sustainability in high weathered soils, such as the Oxisol in the Amazon biome, since it affects the dynamics of the soil organic matter (VALLADARES; BATISTELLA; PEREIRA, 2011), which is the main nutrient source in this ecosystem (SILVA; SILVA JÚNIOR; MELO, 2006). Changes in soil organic matter content have direct and indirect consequences on the soil chemical characteristics, thus, studying the effects of tillage systems on soil fertility is strategic for environmental preservation (BAYER; BERTOL, 1999; CUNHA et al., 2007). According to Luizão (2007), the conversion of forests into pasture and crops, changes the organic matter dynamics and nutrient cycling in the Amazon biome, decreasing the soil productive capacity with time, depending on the management established. Thus, the objective of this work was to identify and evaluate the main changes in soil fertility properties resulting from the use and management of an Oxisol (Latossolo Vermelho-amarelo, SiBCS) in the Amazon biome, aiming the mitigation of degradation in this agroecosystem.

\section{MATERIAL AND METHODS}

The experiment was conducted in the Veridiana Farm $\left(10^{\circ} 02^{\prime} 29^{\prime \prime S}\right.$; 56 06 $\left.41^{\prime \prime} \mathrm{W}\right)$, Alta Floresta, northern Mato Grosso State, Brazil, in the Amazon biome. The region climate is tropical rainy with a dry season, according to the Köppen classification, with temperatures of $20-38^{\circ} \mathrm{C}$ and annual average precipitation of $2700 \mathrm{~mm}$, and has average altitude of $320 \mathrm{~m}$.

The soil uses and management systems evaluated were conducted in an Oxisol (Latossolo Vermelho-amarelo, SiBCS) of medium texture, however, it was adjacent to a soil of sandy texture (with clay content of $120-160 \mathrm{~g} \mathrm{~kg}^{-1}$ at $0.40 \mathrm{~m}$ ).

Pasture areas prepared with minimum tillage and conventional tillage systems were implemented for evaluation. Native pasture and native forest areas were also evaluated, both were adjacent to the systems with mechanical preparation (Table 1). A completely randomized experimental design was used, with seven replications and plot areas of $70 \mathrm{~m}^{2}$.

The species Brachiaria brizantha cv. Marandu was used for planting and the areas were conducted for beef cattle under extensive pasture system, with an average of 2.4 animal unit $(450 \mathrm{~kg})$ $\mathrm{ha}^{-1}$. Five single soil samples were randomly collected, using a Dutch auger, in the areas one year after the implementation of the pastures with minimum tillage and conventional tillage systems. The single samples were homogenized to form a composite sample in each repetition of the different soil uses and managements. The layers $0.00-0.10$, $0.10-0.20,0.20-0.30$ and $0.30-0.40 \mathrm{~m}$ were sampled. The sampled soil was air-dried for 72 hours and passed through a $2 \mathrm{~mm}$-mesh sieve, in order to obtain the air-dried ground soil (ADGS) for further analysis. 
Table 1. Description of the experimental areas (treatments).

\begin{tabular}{|c|c|}
\hline Soil uses and management systems & Description \\
\hline Native forest & Dense forest with absence of human intervention, used as a reference \\
\hline Native pasture & $\begin{array}{l}\text { Grass vegetation with predominance of Brachiaria brizantha cv. Marandu } \\
\text { since } 1989 \text {, conducted without any soil chemical management. The native } \\
\text { vegetation was deforested and burned for land clearance and seeds were } \\
\text { broadcast for the pasture implementation. }\end{array}$ \\
\hline Minimum tillage system & $\begin{array}{l}\text { Rice and soybeans crops were conducted from } 2003 \text { to } 2007 \text { using the } \\
\text { conventional tillage system. A subsoiling to a depth of } 35 \mathrm{~cm} \text { was carried } \\
\text { out for the implementation of the last annual crop in } 2006 \text {. Brachiaria } \\
\text { brizantha cv. Marandu was planted after the } 2007 \text { crop. A liming was } \\
\text { performed }\left(1 \mathrm{Mg} \mathrm{ha}^{-1}\right) \text { during the grain crops. Nitrogen fertilizers ( } 120 \mathrm{~kg} \\
\left.\mathrm{ha}^{-1}\right) \text { were applied for the rice crops. }\end{array}$ \\
\hline Conventional tillage system & $\begin{array}{l}\text { Rice and soybeans crop were conducted from } 2003 \text { to } 2007 \text { using the } \\
\text { conventional tillage system. Disk plow and harrow leveling to a depth of } \\
20 \mathrm{~cm} \text { depth was used for the implementation of the last annual crop in } \\
2006 \text {. Brachiaria brizantha cv. Marandu was planted after the } 2007 \mathrm{crop} \text {. } \\
\left.\text { A liming was performed }(1 \mathrm{Mg} \mathrm{ha})^{-1}\right) \text { during the grain crops. Nitrogen } \\
\text { fertilizers }\left(120 \mathrm{~kg} \mathrm{ha}^{-1}\right) \text { were applied for the rice crops. }\end{array}$ \\
\hline
\end{tabular}

The air-dried ground soil (ADGS) sampled from each plot were used to assess the chemical properties of soil fertility, evaluating the $\mathrm{pH}\left(\mathrm{CaCl}_{2}\right)$, exchangeable $\mathrm{P}$ and $\mathrm{K}$ (Mehlich-1), exchangeable $\mathrm{Ca}, \mathrm{Mg}$ and $\mathrm{Al}\left(\mathrm{KCl} 1 \mathrm{~mol} \mathrm{~L}^{-1}\right)$ and organic matter (DONAGEMA et al., 2011). The aluminum saturation, sum of bases, base saturation, effective cation exchange capacity (CEC) and potential CEC were also evaluated.

The data were subjected to analysis of variance and the means were compared by the Tukey's test at $1 \%$ of significance, using the statistical software SISVAR ${ }^{\circledR}$ (FERREIRA, 2011). The Pearson's correlation was also applied to the variables, considering the entire data set (28 evaluations of each treatment, resulting from 7 replications in 4 sampled depths).

\section{RESULTS AND DISCUSSION}

The highest $\mathrm{pH}$ values in all soil layers evaluated were found in the native pasture area (Table 2). However, these values are within the range class of acid soils. The minimum tillage had higher $\mathrm{pH}$ values than the conventional tillage system in the layers $0.00-0.10$ and $0.10-0.20 \mathrm{~m}$. The minimum and conventional tillage systems showed no significant difference in the layers $0.20-0.30$ and $0.30-0.40 \mathrm{~m}$. The $\mathrm{pH}$ of the native forest and native pasture areas decreased with depth, while the minimum tillage system had a $\mathrm{pH}$ decrease only in the layer $0.30-0.40 \mathrm{~m}$, and the conventional tillage area showed no $\mathrm{pH}$ change with depth.

The highest $\mathrm{pH}$ values of the native pasture area are related to the characteristics of the organic matter from the litterfall deposition and dead roots, which mineralize, contributing to the increase of negative charges and soil pH (SARMENTO et al., 2008). Franchini et al., (1999) found a decrease in $\mathrm{pH}$ values with depth in native forest and native pasture areas, as found in the present study. Valladares, Batistella and Pereira (2011) evaluated the effect of land use on chemical properties of soils of the Amazon biome and found higher $\mathrm{pH}$ in pasture areas, compared with native forest areas. Bayer and Bertol (1999) found no significant difference in soil $\mathrm{pH}$ depending on the management systems (minimum tillage and conventional tillage).

Table 2. $\mathrm{pH}$ values, $\mathrm{Al}^{3+}$ contents and aluminum saturation ( $\mathrm{m} \%$ ) of an Oxisol in the Amazon biome, depending on soil uses and management systems.

\begin{tabular}{ccccc}
\hline \multirow{2}{*}{$\begin{array}{c}\text { Layers } \\
(\mathrm{m})\end{array}$} & \multicolumn{4}{c}{ Soil uses and management systems } \\
\cline { 2 - 4 } & Native forest & Native pasture & Minimum tillage & Conventional tillage \\
\hline $0.00-0.10$ & $4.1 \mathrm{c}$ & $\mathrm{pH}\left(\mathrm{CaCl}_{2}\right)$ & $3.9 \mathrm{~d}$ \\
$0.10-0.20$ & $4.1 \mathrm{c}$ & $4.7 \mathrm{a}$ & $4.4 \mathrm{~b}$ & $3.9 \mathrm{~d}$ \\
$0.20-0.30$ & $4.0 \mathrm{~b}$ & $4.7 \mathrm{a}$ & $4.3 \mathrm{~b}$ & $4.0 \mathrm{~b}$ \\
$0.30-0.40$ & $3.9 \mathrm{~b}$ & $4.7 \mathrm{a}$ & $4.0 \mathrm{~b}$ & $4.0 \mathrm{~b}$ \\
\hline
\end{tabular}

Means followed by different letters in the rows differ by the Tukey's test at $1 \%$ significance. 
Table 2. Continuation.

\begin{tabular}{|c|c|c|c|c|}
\hline \multirow{2}{*}{$\begin{array}{c}\text { Layers } \\
(\mathrm{m})\end{array}$} & \multicolumn{4}{|c|}{ Soil uses and management systems } \\
\hline & Native forest & Native pasture & Minimum tillage & Conventional tillage \\
\hline & \multicolumn{4}{|c|}{$\mathrm{Al}^{3+}\left(\mathrm{cmol}_{\mathrm{c}} \mathrm{dm}^{-3}\right)$} \\
\hline $0.00-0.10$ & $0.3 \mathrm{~b}$ & $0.1 \mathrm{c}$ & $0.2 \mathrm{c}$ & $0.6 \mathrm{a}$ \\
\hline $0.10-0.20$ & $0.5 \mathrm{a}$ & $0.2 \mathrm{~b}$ & $0.2 \mathrm{~b}$ & $0.6 \mathrm{a}$ \\
\hline $0.20-0.30$ & $0.6 \mathrm{a}$ & $0.3 \mathrm{~b}$ & $0.5 \mathrm{ab}$ & $0.5 \mathrm{ab}$ \\
\hline \multirow[t]{2}{*}{$0.30-0.40$} & $0.6 \mathrm{a}$ & $0.3 \mathrm{~b}$ & $0.5 \mathrm{a}$ & $0.5 \mathrm{a}$ \\
\hline & \multicolumn{4}{|c|}{$\mathrm{m} \%$} \\
\hline $0.00-0.10$ & $13 \mathrm{~b}$ & $6 \mathrm{~b}$ & $7 b$ & $40 \mathrm{a}$ \\
\hline $0.10-0.20$ & $21 \mathrm{~b}$ & $9 \mathrm{c}$ & $13 \mathrm{bc}$ & $46 \mathrm{a}$ \\
\hline $0.20-0.30$ & $46 \mathrm{a}$ & $16 \mathrm{~b}$ & $36 \mathrm{ab}$ & $44 \mathrm{a}$ \\
\hline $0.30-0.40$ & $56 \mathrm{a}$ & $20 \mathrm{~b}$ & $41 \mathrm{ab}$ & $48 \mathrm{a}$ \\
\hline
\end{tabular}

Means followed by different letters in the rows differ by the Tukey's test at $1 \%$ significance.

The highest exchangeable aluminum contents were found in the soil layers 0.00-0.10 and $0.10-0.20 \mathrm{~m}$ of the conventional tillage system, while the layer $0.30-0.40 \mathrm{~m}$ was different only from the natural pasture, with lower $\mathrm{Al}^{3+}$ contents, compared with other management systems (Table 2), due to the its low acidity (higher $\mathrm{pH}$ ) with depth. The minimum tillage system had lower aluminum contents, with higher $\mathrm{pH}$ values, compared with the conventional tillage. Aluminum contents increased with depth, except for the conventional tillage system, which presented uniform contents along the soil profile.

The increase in $\mathrm{pH}$ usually decreases the solubility of the toxic aluminum in the soil, while the organic matter causes the complexation of this element (FALLEIRO et al., 2003). Silva Neto et al. (2011) evaluated the land use in a Cerrado-Amazon transition area and found aluminum contents 3-fold higher in the native forest area compared with a pasture area. Bayer and Bertol (1999) found no differences in aluminum contents between minimum and conventional tillage systems.

The minimum tillage system had aluminum saturation lower than the conventional tillage (Table 2), which is related to its lower toxic aluminum content. The aluminum saturation increased with depth, except in the conventional tillage system, which had uniform saturation along the soil profile. On the other hand, Lourente et al. (2011) found higher aluminum saturation in pasture areas compared with native forest and conventional tillage areas.

The native forest and minimum tillage had higher phosphorus availability in the layer $0.00-0.10 \mathrm{~m}$ (Table 3). The soil uses and management systems showed no significant differences in phosphorus availability in the other layers. Only the native forest showed decrease in phosphorus availability at depths below $0.10 \mathrm{~m}$. The absence of tilling and maintenance of forest residues on the soil surface in the native forest area probably contributed to increase the phosphorus availability in the surface layer (FALLEIRO et al., 2003). Lourente et al. (2011) found higher phosphorus availability in the native forest area comparing with pasture and conventional tillage areas.

The highest potassium availabilities, in all soil layers evaluated, were found in the minimum tillage system (Table 4). All soil uses and management systems showed a decrease in potassium availability with depth. Potassium moves in the soil predominantly by diffusion and its availability is generally higher in systems of little soil disturbance, since greater organic matter contents are found in surface layers (ERNANI; ALMEIDA; SANTOS, 2007), contributing to the cation exchange capacity (CEC) of the soil surface and, consequently, to a greater nutrient retention and lower leaching rate. The results found in the present work confirm those found by Lourente et al. (2011), who found similar potassium availability in native forest and native pasture areas, and by Bayer and Bertol (1999), who found higher potassium availability in a minimum tillage compared with a conventional tillage system.

The lower values of calcium, magnesium and the sum of bases were found in the layers $0.00-0.10$ and $0.10-0.20 \mathrm{~m}$ of the conventional tillage, while the other systems showed no significant differences (Table 3). The soil layers $0.20-0.30$ and $0.30-0.40$ showed higher values in the native pasture, while the others soil uses and management systems showed no significant differences. The values of calcium, magnesium and sum of bases decreased with depth, except for the conventional tillage system, which showed uniform values along the soil profile. 
M. RODRIGUES et al

Table 3. Available phosphorus, potassium, calcium and magnesium, sum of bases and base saturation of an Oxisol in the Amazon biome, depending on soil uses and management systems.

\begin{tabular}{|c|c|c|c|c|}
\hline \multirow{2}{*}{$\begin{array}{c}\text { Layers } \\
(\mathrm{m})\end{array}$} & \multicolumn{4}{|c|}{ Soil uses and management systems } \\
\hline & Native forest & Native pasture & Minimum tillage & Conventional tillage \\
\hline & \multicolumn{4}{|c|}{ Available $\mathrm{P}\left(\mathrm{mg} \mathrm{dm}^{-3}\right)$} \\
\hline $0.00-0.10$ & $2.3 \mathrm{a}$ & $0.9 \mathrm{~b}$ & $1.5 \mathrm{ab}$ & $1.1 \mathrm{~b}$ \\
\hline $0.10-0.20$ & $0.9 \mathrm{a}$ & $0.7 \mathrm{a}$ & $0.9 \mathrm{a}$ & $1.0 \mathrm{a}$ \\
\hline $0.20-0.30$ & $0.6 \mathrm{a}$ & $0.6 \mathrm{a}$ & $0.5 \mathrm{a}$ & $0.3 \mathrm{a}$ \\
\hline \multirow[t]{2}{*}{$0.30-0.40$} & $0.5 \mathrm{a}$ & $0.5 \mathrm{a}$ & $0.4 \mathrm{a}$ & $0.2 \mathrm{a}$ \\
\hline & \multicolumn{4}{|c|}{ Potassium $\left(\mathrm{cmol}_{\mathrm{c}} \mathrm{dm}^{-3}\right)$} \\
\hline $0.00-0.10$ & $0.21 \mathrm{~b}$ & $0.21 \mathrm{~b}$ & $0.28 \mathrm{a}$ & $0.15 \mathrm{~b}$ \\
\hline $0.10-0.20$ & $0.15 \mathrm{~b}$ & $0.15 \mathrm{~b}$ & $0.21 \mathrm{a}$ & $0.13 \mathrm{~b}$ \\
\hline $0.20-0.30$ & $0.08 \mathrm{c}$ & $0.11 \mathrm{~b}$ & $0.16 \mathrm{a}$ & $0.11 \mathrm{~b}$ \\
\hline \multirow[t]{2}{*}{$0.30-0.40$} & $0.06 \mathrm{c}$ & $0.09 \mathrm{~b}$ & $0.15 \mathrm{a}$ & $0.08 \mathrm{bc}$ \\
\hline & \multicolumn{4}{|c|}{ Calcium $\left(\mathrm{cmol}_{\mathrm{c}} \mathrm{dm}^{-3}\right)$} \\
\hline $0.00-0.10$ & $1.5 \mathrm{a}$ & $1.2 \mathrm{a}$ & $1.2 \mathrm{a}$ & $0.5 \mathrm{~b}$ \\
\hline $0.10-0.20$ & $1.2 \mathrm{a}$ & $1.0 \mathrm{a}$ & $0.9 \mathrm{a}$ & $0.4 \mathrm{~b}$ \\
\hline $0.20-0.30$ & $0.4 \mathrm{~b}$ & $0.9 \mathrm{a}$ & $0.4 \mathrm{~b}$ & $0.3 \mathrm{~b}$ \\
\hline \multirow[t]{2}{*}{$0.30-0.40$} & $0.3 \mathrm{~b}$ & $0.7 \mathrm{a}$ & $0.3 \mathrm{~b}$ & $0.3 \mathrm{~b}$ \\
\hline & \multicolumn{4}{|c|}{ Magnesium $\left(\mathrm{cmol}_{\mathrm{c}} \mathrm{dm}^{-3}\right)$} \\
\hline $0.00-0.10$ & $0.8 \mathrm{a}$ & $0.9 \mathrm{a}$ & $0.9 \mathrm{a}$ & $0.3 \mathrm{~b}$ \\
\hline $0.10-0.20$ & $0.7 \mathrm{a}$ & $0.7 \mathrm{a}$ & $0.6 \mathrm{a}$ & $0.2 \mathrm{~b}$ \\
\hline $0.20-0.30$ & $0.3 \mathrm{~b}$ & $0.7 \mathrm{a}$ & $0.3 \mathrm{~b}$ & $0.2 \mathrm{~b}$ \\
\hline \multirow[t]{2}{*}{$0.30-0.40$} & $0.2 \mathrm{~b}$ & $0.4 \mathrm{a}$ & $0.3 \mathrm{~b}$ & $0.2 \mathrm{~b}$ \\
\hline & \multicolumn{4}{|c|}{ Sum of bases $\left(\mathrm{cmol}_{\mathrm{c}} \mathrm{dm}^{-3}\right)$} \\
\hline $0.00-0.10$ & $2.5 \mathrm{a}$ & $2.2 \mathrm{a}$ & $2.3 \mathrm{a}$ & $1.0 \mathrm{~b}$ \\
\hline $0.10-0.20$ & $2.0 \mathrm{a}$ & $1.9 \mathrm{a}$ & $1.7 \mathrm{a}$ & $0.7 \mathrm{~b}$ \\
\hline $0.20-0.30$ & $0.7 \mathrm{~b}$ & $1.7 \mathrm{a}$ & $0.8 \mathrm{~b}$ & $0.7 \mathrm{~b}$ \\
\hline \multirow[t]{2}{*}{$0.30-0.40$} & $0.6 \mathrm{~b}$ & $1.2 \mathrm{a}$ & $0.7 \mathrm{~b}$ & $0.6 \mathrm{~b}$ \\
\hline & \multicolumn{4}{|c|}{ Base saturation $(\%)$} \\
\hline $0.00-0.10$ & $25.1 \mathrm{~b}$ & $37.7 \mathrm{a}$ & $31.2 \mathrm{ab}$ & $15.1 \mathrm{c}$ \\
\hline $0.10-0.20$ & $21.6 \mathrm{~b}$ & $36.8 \mathrm{a}$ & $24.0 \mathrm{~b}$ & $11.9 \mathrm{c}$ \\
\hline $0.20-0.30$ & $10.8 \mathrm{~b}$ & $32.9 \mathrm{a}$ & $13.8 \mathrm{~b}$ & $12.6 \mathrm{~b}$ \\
\hline $0.30-0.40$ & $9.5 \mathrm{~b}$ & $26.2 \mathrm{a}$ & $12.0 \mathrm{~b}$ & $11.7 \mathrm{~b}$ \\
\hline
\end{tabular}

Means followed by different letters in the rows differ by the Tukey's test at $1 \%$ significance.

The calcium and magnesium contents are commonly higher in conditions of deposition of organic residues, as in the native forest and native pasture areas, and conditions of little soil disturbance, as in the minimum tillage, compared with systems of high soil disturbance, because the recycling of nutrients by the plants, which contributes to increase the sum of bases (FALLEIRO et al., 2003). The organic matter content is lower at greater depths (ERNANI; ALMEIDA; SANTOS, 2007), causing loss of potassium, calcium and magnesium by leaching, decreasing the sum of bases
(CAIRES et al., 1998).

De Souza Braz, Fernandes and Alleoni (2013) found higher calcium and magnesium contents in pasture areas, contributing to increase the sum of bases, compared with native forest areas. Bayer and Bertol (1999) found higher calcium contents in the soil surface layer in a minimum tillage system compared with a conventional tillage, and attributed this result to the nutrient cycling by the phytomass deposition on the soil surface. These authors found no significant differences in magnesium contents between the areas, in the soil surface layer. 
The highest values of base saturation were found in the soil layers $0.10-0.20,0.20-0.30$ and $0.30-0.40 \mathrm{~m}$ of the native pasture area (Table 3 ). The layer $0-0.10 \mathrm{~m}$ of the native pasture also showed higher base saturation, compared with the native forest and the conventional tillage systems. The minimum tillage area had base saturations higher than the conventional tillage in the layers $0.00-0.10$ and $0.10-0.20 \mathrm{~m}$. The base saturation of the native forest and minimum tillage systems decreased with depth, the first only in the layer $0.30-0.40 \mathrm{~m}$; and the conventional tillage showed uniform values of base saturation along the soil profile.

These values are related to the changes in aluminum, potassium, calcium and magnesium contents in the soil profile of each soil use and management system, which directly affects the base saturation values, as pointed out by Araújo et al., (2011). De Souza Braz, Fernandes and Alleoni (2013) also found higher base saturation in pasture areas, compared with a native forest area, as well as Pereira et al. (2009) who found higher base saturation in a minimum tillage system, compared with a conventional tillage.

The minimum tillage area had higher organic matter content (Table 4) than the conventional tillage, in the layers $0-0.10,0.10-0.20$ and $0.20-0.30 \mathrm{~m}$. The organic matter content reduced with depth in all soil uses and management systems.

The continuous deposition of plant material and lack of soil tilling in native forest areas strongly contribute to increase the organic matter content in the soil (ARAÚJO et al., 2011; SATO et al., 2012). The soil tilling in conventional tillage contributes to the organic matter exposure and oxidation, thus, systems that have the less intense soil tilling, such as minimum tillage, contribute to increase the soil organic matter contents (BAYER; BERTOL, 1999). Lourente et al. (2011) reported higher organic matter contents in a native forest area compare with a native pasture. Santos and Tomm (2003) found higher organic matter content in the soil layer $0.00-0.10 \mathrm{~m}$ of a minimum tillage area compared with a conventional tillage area.

Table 4. Soil organic matter, effective cation exchange capacity (CEC) and potential CEC in an Oxisol in the Amazon biome, depending on soil uses and management systems.

\begin{tabular}{|c|c|c|c|c|}
\hline \multirow{2}{*}{$\begin{array}{c}\text { Layers } \\
(\mathrm{m})\end{array}$} & \multicolumn{4}{|c|}{ Soil uses and management systems } \\
\hline & Native forest & Native pasture & Minimum tillage & Conventional tillage \\
\hline & \multicolumn{4}{|c|}{ Soil organic matter $\left(\mathrm{g} \mathrm{kg}^{-1}\right)$} \\
\hline $0.00-0.10$ & $22.9 \mathrm{a}$ & $16.4 \mathrm{c}$ & $20.5 \mathrm{~b}$ & $16.1 \mathrm{c}$ \\
\hline $0.10-0.20$ & $19.6 \mathrm{a}$ & $11.5 \mathrm{~b}$ & $17.8 \mathrm{a}$ & $13.9 \mathrm{~b}$ \\
\hline $0.20-0.30$ & $12.0 \mathrm{ab}$ & $8.7 \mathrm{c}$ & $13.5 \mathrm{a}$ & $9.3 \mathrm{bc}$ \\
\hline \multirow[t]{2}{*}{$0.30-0.40$} & $11.4 \mathrm{a}$ & $8.0 \mathrm{~b}$ & $10.9 \mathrm{ab}$ & $8.6 \mathrm{~b}$ \\
\hline & \multicolumn{4}{|c|}{ Effective CEC $\left(\mathrm{cmol}_{\mathrm{c}} \mathrm{dm}^{-3}\right)$} \\
\hline $0.00-0.10$ & $2.8 \mathrm{a}$ & $2.4 \mathrm{a}$ & $2.5 \mathrm{a}$ & $1.6 \mathrm{~b}$ \\
\hline $0.10-0.20$ & $2.5 \mathrm{a}$ & $2.1 \mathrm{~b}$ & $2.0 \mathrm{~b}$ & $1.3 \mathrm{c}$ \\
\hline $0.20-0.30$ & $1.4 \mathrm{~b}$ & $2.0 \mathrm{a}$ & $1.3 \mathrm{~b}$ & $1.2 \mathrm{~b}$ \\
\hline \multirow[t]{2}{*}{$0.30-0.40$} & $1.2 \mathrm{a}$ & $1.5 \mathrm{a}$ & $1.2 \mathrm{a}$ & $1.1 \mathrm{a}$ \\
\hline & \multicolumn{4}{|c|}{ Potential CEC $\left(\mathrm{cmol}_{\mathrm{c}} \mathrm{dm}^{-3}\right)$} \\
\hline $0.00-0.10$ & $9.7 \mathrm{a}$ & $6.1 \mathrm{c}$ & $7.5 \mathrm{~b}$ & $6.3 \mathrm{c}$ \\
\hline $0.10-0.20$ & $9.1 \mathrm{a}$ & $5.1 \mathrm{~d}$ & $7.1 \mathrm{~b}$ & $6.0 \mathrm{c}$ \\
\hline $0.20-0.30$ & $6.8 \mathrm{a}$ & $5.0 \mathrm{c}$ & $6.0 \mathrm{~b}$ & $5.2 \mathrm{c}$ \\
\hline $0.30-0.40$ & $5.9 \mathrm{a}$ & $4.6 \mathrm{~b}$ & $5.8 \mathrm{a}$ & $4.7 \mathrm{~b}$ \\
\hline
\end{tabular}

Means followed by different letters in the rows differ by the Tukey's test at $1 \%$ significance.

The soil layer $0.00-0.10 \mathrm{~m}$ of the conventional tillage system had the lowest effective CEC values (Table 4), while the others soil uses and management systems showed no significant differences. The native forest and native pasture areas showed higher effective CEC values in the layer $0.10-0.20 \mathrm{~m}$, while the native pasture showed higher value in the layer $0.20-0.30 \mathrm{~m}$. The soil uses and management systems had no significant differences in the layer $0.30-0.40 \mathrm{~m}$ regarding the effective CEC. The effective CEC values reduced with depth in all soil uses and management systems.

The effective CEC values found are related to the $\mathrm{pH}$ values and organic matter content of the soil uses and management systems, since the $\mathrm{pH}$ and organic matter directly affect the effective CEC. These results are also related to the marked contribution of variable charges in the mineral fraction, which are found mainly in weathered tropical soils (MENDONÇA; ROWELL, 1996). The 
organic matter also contributes to balance negative charges and decrease the hydrogen activity $\left(\mathrm{H}^{+}\right)$, which is also affected by cations in the soil solution (FALLEIRO et al., 2003). The results found in the present work differ from those found by De Souza Braz, Fernandes and Alleoni (2013), who found higher effective CEC in a pasture compared with a native forest area, and by Pereira et al. (2009), who found no significant differences in CEC values between minimum tillage and conventional tillage systems.

The highest potential CEC values were found in the soil layers $0.00-0.10, \quad 0.10-0.20$ and $0.20-0.30 \mathrm{~m}$ of the native forest area (Table 4 ). The native forest and minimum tillage areas had higher potential CEC values in the layer $0.30-0.40 \mathrm{~m}$. The minimum tillage system had higher potential CEC values than the conventional tillage and native pasture in all soil layers evaluated. These results were mainly due to the effect of the organic matter content, which is responsible for much of the soil negative charges (BAYER; BERTOL, 1999). De Souza Braz, Fernandes and Alleoni (2013) also found higher potential CEC in a native forest area compared with a pasture area.

The phosphorus showed no significant correlation with any chemical property of soil fertility in the native forest, unlike the others soil management systems (Table 5).

The native pasture area showed no correlation between $\mathrm{pH}$ values and contents of phosphorus, potassium and soil organic matter. All indicative parameters of soil fertility showed correlation with each other in the minimum tillage system. The conventional tillage showed no correlation between $\mathrm{pH}$ values and aluminum contents; calcium and magnesium contents; and magnesium and soil organic matter contents.

According to the correlations between chemical properties of soil fertility in the different soil managements, the system with greater soil disturbances (conventional tillage) showed no significant correlations between $\mathrm{pH}$ values and nutrients, differing from the other soil uses and managements. On the other hand, the correlations between the nutrient and organic matter contents showed proportional and highly significant correlations $(>0.79)$ between SOM and available P and exchangeable $\mathrm{K}$. This result may be related to the capacity of the organic matter in maintaining soil fertility, even in the most fragile systems (conventional tillage), from the soil conservation point of view.

According to the results, the soil uses and management systems affected the soil chemical properties, soil $\mathrm{pH}$ and the contents of organic matter, $\mathrm{Al}^{3+}, \mathrm{P}, \mathrm{K}^{+}, \mathrm{Ca}^{2+}$ and $\mathrm{Mg}^{2+}$. Therefore, changes in these properties must be taken into account for a proper soil management, in order to increase the agricultural efficiency and reduce environmental degradation.

Table 5. Pearson's correlation coefficient between chemical properties of soil fertility of an Oxisol in the Amazon biome, depending on soil uses and management systems ${ }^{1}$.

\begin{tabular}{|c|c|c|c|c|c|c|c|}
\hline & \multicolumn{7}{|c|}{ Native forest } \\
\hline & $\mathrm{pH}$ & $\mathrm{Al}^{3+}$ & P-Mehlich & $\mathrm{K}^{+}$ & $\mathrm{Ca}^{2+}$ & $\mathrm{Mg}^{2+}$ & SOM \\
\hline $\mathrm{pH}$ & 1 & - & - & - & - & - & - \\
\hline $\mathrm{Al}^{3+}$ & $-0.89 * *$ & 1 & - & - & - & - & - \\
\hline P-Mehlich & $0.11 \mathrm{NS}$ & $-0.26 \mathrm{NS}$ & 1 & - & - & - & - \\
\hline $\mathrm{K}^{+}$ & $0.74 * *$ & $-0.72 * *$ & $0.28 \mathrm{NS}$ & 1 & - & - & - \\
\hline $\mathrm{Ca}^{2+}$ & $0.92 * *$ & $-0.84 * *$ & $0.17 \mathrm{NS}$ & $0.75^{* *}$ & 1 & - & - \\
\hline $\mathrm{Mg}^{2+}$ & $0.89 * *$ & $-0.82 * *$ & $0.18 \mathrm{NS}$ & $0.82 * *$ & $0.88^{* *}$ & 1 & - \\
\hline \multirow[t]{3}{*}{$\mathrm{SOM}$} & $0.73 * *$ & $-0.71 * *$ & $0.24 \mathrm{NS}$ & $0.87 * *$ & $0.70 * *$ & $0.86^{* *}$ & 1 \\
\hline & \multicolumn{7}{|c|}{ Native pasture } \\
\hline & $\mathrm{pH}$ & $\mathrm{Al}^{3+}$ & P-Mehlich & $\mathrm{K}^{+}$ & $\mathrm{Ca}^{2+}$ & $\mathrm{Mg}^{2+}$ & SOM \\
\hline $\mathrm{pH}$ & 1 & - & - & - & - & - & - \\
\hline $\mathrm{Al}^{3+}$ & $-0.55 * *$ & 1 & - & - & - & - & - \\
\hline P-Mehlich & $0.28 \mathrm{NS}$ & $-0.48^{* *}$ & 1 & - & - & - & - \\
\hline $\mathrm{K}^{+}$ & $0.25 \mathrm{NS}$ & $-0.53 * *$ & $0.75^{* *}$ & 1 & - & - & - \\
\hline $\mathrm{Ca}^{2+}$ & $0.64 * *$ & $-0.65^{* *}$ & $0.54^{* *}$ & $0.56^{* *}$ & 1 & - & - \\
\hline $\mathrm{Mg}^{2+}$ & $0.58 * *$ & $-0.65^{* *}$ & $0.61 * *$ & $0.64^{* *}$ & $0.75^{* *}$ & 1 & - \\
\hline SOM & $0.24 \mathrm{NS}$ & $-0.48 * *$ & $0.80 * *$ & $0.83 * *$ & $0.54 * *$ & $0.61 * *$ & 1 \\
\hline
\end{tabular}

*Significant at $5 \%$. **Significant at $1 \%$. NS $=$ not significant. $\mathrm{SOM}=$ soil organic matter. ${ }^{1}$ Values referring to the analysis of the entire data set (seven replications of the layers $0.00-0.10,0.10-0.20,0.20-0.30$ and $0.30-0.40 \mathrm{~m}$ ). 
Table 5. Continuation.

\begin{tabular}{|c|c|c|c|c|c|c|c|}
\hline & \multicolumn{7}{|c|}{ Minimum tillage } \\
\hline & $\mathrm{pH}$ & $\mathrm{Al}^{3+}$ & P-Mehlich & $\mathrm{K}^{+}$ & $\mathrm{Ca}^{2+}$ & $\mathrm{Mg}^{2+}$ & SOM \\
\hline $\mathrm{pH}$ & 1 & - & - & - & - & - & - \\
\hline $\mathrm{Al}^{3+}$ & $-0.88^{* *}$ & 1 & - & - & - & - & - \\
\hline P-Mehlich & $0.74^{* *}$ & $-0.80^{* *}$ & 1 & - & - & - & - \\
\hline $\mathrm{K}^{+}$ & $0.76^{* *}$ & $-0.76^{* *}$ & $0.79 * *$ & 1 & - & - & - \\
\hline $\mathrm{Ca}^{2+}$ & $0.88 * *$ & $-0.89 * *$ & $0.82 * *$ & $0.77 * *$ & 1 & - & - \\
\hline $\mathrm{Mg}^{2+}$ & $0.78 * *$ & $-0.85^{* *}$ & $0.85^{* *}$ & $0.77 * *$ & $0.90 * *$ & 1 & - \\
\hline \multirow[t]{3}{*}{ SOM } & $0.83 * *$ & $-0.85 * *$ & $0.82 * *$ & $0.83 * *$ & $0.88 * *$ & $0.83 * *$ & 1 \\
\hline & \multicolumn{7}{|c|}{ Conventional tillage } \\
\hline & $\mathrm{pH}$ & $\mathrm{Al}^{3+}$ & P-Mehlich & $\mathrm{K}^{+}$ & $\mathrm{Ca}^{2+}$ & $\mathrm{Mg}^{2+}$ & SOM \\
\hline $\mathrm{pH}$ & 1 & - & - & - & - & - & - \\
\hline $\mathrm{Al}^{3+}$ & $-0.76^{* *}$ & 1 & - & - & - & - & - \\
\hline P-Mehlich & $-0.26 \mathrm{NS}$ & $0.54 * *$ & 1 & - & - & - & - \\
\hline $\mathrm{K}^{+}$ & $-0.11 \mathrm{NS}$ & $0.39^{*}$ & $0.81 * *$ & 1 & - & - & - \\
\hline $\mathrm{Ca}^{2+}$ & $0.34 \mathrm{NS}$ & $-0.20 \mathrm{NS}$ & $0.41 *$ & $0.52 * *$ & 1 & - & - \\
\hline $\mathrm{Mg}^{2+}$ & $0.21 \mathrm{NS}$ & $-0.19 \mathrm{NS}$ & $0.37^{*}$ & $0.50 * *$ & $0.56^{* *}$ & 1 & - \\
\hline SOM & $-0.13 \mathrm{NS}$ & $0.49 * *$ & $0.88^{* *}$ & $0.79 * *$ & $0.46^{*}$ & $0.36 \mathrm{NS}$ & 1 \\
\hline
\end{tabular}

*Significant at $5 \%$. **Significant at $1 \%$. NS $=$ not significant. $\mathrm{SOM}=$ soil organic matter. ${ }^{1}$ Values referring to the analysis of the entire data set (seven replications of the layers $0.00-0.10,0.10-0.20,0.20-0.30$ and $0.30-0.40 \mathrm{~m}$ ).

\section{CONCLUSIONS}

The fertility of the Amazonian Oxisol were changed by the soil uses and management systems.

The soil acidity in the surface layer (0.00-0.20 m) was higher when the implantation of pasture (Brachiaria brizantha cv. Marandu) was conducted using the conventional tillage system, compared with the minimum tillage system.

The nutrient availability for the plants was reduced with the use of soil conventional tillage, compared with the minimum tillage system.

The tendency of increasing $\mathrm{pH}$ and, consequently, nutrient exchangeable contents was not maintained under the conventional tillage system. The effect of the organic matter, in this case, was more evident.

Soil uses and management systems of little soil disturbance, such as the minimum tillage system, are recommended to minimize environmental degradation in the Amazon biome.

\section{REFERENCES}

ARAÚJO, E. A. et al. Impacto da conversão floresta - pastagem nos estoques e na dinâmica do carbono e substâncias húmicas do solo no bioma Amazônico. Acta Amazônica, Manaus, v. 41, n. 1, p. 103-114, 2011.
BAYER, C.; BERTOL, I. Características químicas de um Cambissolo húmico afetadas por sistemas de preparo, com ênfase à matéria orgânica. Revista Brasileira de Ciência do Solo, Viçosa, v. 23, n. 3, p. 687-694, 1999.

CAIRES, E. F. et al. Alterações de características químicas do solo e resposta da soja ao calcário e gesso aplicados na superfície em sistema de cultivo sem preparo do solo. Revista Brasileira de Ciência do Solo, Viçosa, v. 22, n. 1, p. 27-34, 1998.

CUNHA, T. J. F. et al. Fracionamento químico da matéria orgânica e características de ácidos húmicos de solos com horizonte a antrópico da amazônia (Terra Preta). Acta Amazonica, Manaus, v. 37, n. 1, p. $91-98,2007$.

DE SOUZA BRAZ, A. M.; FERNANDES, A. R.; ALLEONI, L. R. F. Soil attributes after the conversion from forest to pasture in Amazon. Land Degradation \& Development, Hoboken, v. 24, n. 1, p. 33-38, 2013.

DONAGEMA, G. K. et al. Manual de métodos de análise de solos. 2. ed. rev. Rio de Janeiro: Embrapa Solos, 2011. 230 p. (Documentos/Embrapa Solos, 132).

ERNANI, P. R.; ALMEIDA, J. A.; SANTOS, F. C. Potássio. In: NOVAIS, R. F. et al. (Eds.). Fertilidade do solo. Viçosa: Sociedade Brasileira de 
Ciência do Solo, 2007. cap. 9, p. 551-594.

FALLEIRO, R. M. et al. Influência dos sistemas de preparo nas propriedades químicas e físicas do solo. Revista Brasileira de Ciência do Solo, Viçosa, v. 27, n. 6, p. 1097-1104, 2003.

FERREIRA, D. F. Sisvar: A computer statistical analysis system. Ciência e Agrotecnologia, Lavras, v. 35, n. 6, p. 1039-1042, 2011.

FRANCHINI, J. C. et al. Alterações químicas em solos ácidos após a aplicação de resíduos vegetais. Revista Brasileira de Ciência do Solo, Viçosa, v. 23, n. 3, p. 533-542, 1999.

LOURENTE, E. R. P. et al. Atributos microbiológicos, químicos e físicos de solo sob diferentes sistemas de manejo e condições de Cerrado. Pesquisa Agropecuária Tropical, Goiânia, v. 41, n. 1, p. 20-28, 2011.

LUIZÃO, F. J. Ciclos de nutrientes na Amazônia: respostas às mudanças ambientais e climáticas. Ciência e Cultura, São Paulo, v. 59, n. 3, p. 31-36, 2007.

MARCOLAN, A. L. et al. Recuperação de atributos físicos de um Argissolo em função do seu revolvimento e do tempo de semeadura direta. Revista Brasileira de Ciência do Solo, Viçosa, v. 31, n. 3, p. 571-579, 2007.

MENDONÇA, E. S.; ROWELL, D. L. Mineral and organic fractions of two Oxisols and their influence on effective cation-exchange capacity. Soil Science Society of American Journal, Madison, v. 60, n. 6, p. 1888-1892, 1996.

MOREIRA, A.; MALAVOLTA, E. Dinâmica da matéria orgânica e da biomassa microbiana em solo submetido a diferentes sistemas de manejo na Amazônia Ocidental. Pesquisa Agropecuária Brasileira, Brasília, v. 39, n. 11, p. 1103-1110, 2004.

MULLER, M. M. L. et al. Degradação de pastagens na Região Amazônica: propriedades físicas do solo e crescimento de raízes. Pesquisa Agropecuária Brasileira, Brasília, v. 36, n. 11, p. 1409-1418, 2001.

PEREIRA, R. G. et al. Atributos químicos do solo influenciados por sistemas de manejo. Revista Caatinga, Mossoró, v. 22, n. 1, p. 78-84, 2009.

SANTOS, H. P. et al. Efeito de sistemas de manejo de solo e de rotação de culturas na fertilidade do solo, após vinte anos. Bragantia, Campinas, v. 67, n. 2, p. 441-454, 2008.
SANTOS, H. P.; TOMM, G. O. Disponibilidade de nutrientes e teor de matéria orgânica em função de sistemas de cultivo e de manejo de solo. Ciência Rural, Santa Maria, v. 33, n. 3, p. 477-486, 2003.

SARMENTO, P. et al. Atributos químicos e físicos de um argissolo cultivado com Panicum maximum JACQ cv. IPR-86 Milênio, sob lotação rotacionada e adubado com nitrogênio. Revista Brasileira de Ciência do Solo, Viçosa, v. 32, n. 1, p. 183-193, 2008.

SASAKI, C. M.; GONÇALVES, J. L. M.; BENTIVENHA, S. R. P. Desempenho operacional de hastes subsoladoras em função da ponteira e do tipo do solo. Scientia Forestalis, Curitiba, v. 67, n. 1, p. 44-52, 2005.

SATO, J. H. et al. Matéria orgânica e infiltração da água em solo sob consórcio milho e forrageiras. Revista Brasileira de Engenharia Agrícola e Ambiental, Campina Grande, v. 16, n. 2, p. 189-193, 2012.

SILVA, G. R.; SILVA JÚNIOR, M. L.; MELO, V. S. Efeitos de diferentes usos da terra sobre as características químicas de um latossolo amarelo do Estado do Pará. Acta Amazônica, Manaus, v. 36, n. 2, p. 151-158, 2006.

SILVA NETO, S. P. et al. Análise espacial de parâmetros da fertilidade do solo em região de ecótono sob diferentes usos e manejos. Semina: Ciências Agrárias, Londrina, v. 32, n. 2, p. 541-552, 2011.

SILVA NETO, S. P. et al. Dependência espacial em levantamentos do estoque de carbono em áreas de pastagens de Brachiaria brizantha cv. Marandu. Acta Amazônica, Manaus, v. 42, n. 4, p. 547-556, 2012 .

TOWNSEND, C. R.; COSTA, N. L.; PEREIRA, R. G. A. Aspectos econômicos da recuperação de pastagens na Amazônia Brasileira. Amazônia: Ciência e Desenvolvimento, Belém, v. 5, n. 1, p. 27 49, 2010.

VALLADARES, G. S.; BATISTELLA, M.; PEREIRA, M. G. Alterações ocorridas pelo manejo em Latossolo, Rondônia, Amazônia Brasileira. Bragantia, Campinas, v. 70, n. 3, p. 631-637, 2011. 